\title{
On Open Systems
}

\author{
Sobre Sistemas Abertos
}

VICTORIA CHICK*,**

RESUMO: Para muitos, a economia é vista como cada vez mais divorciada da realidade. Argumentarei que uma das causas desse divórcio é o apego à teorização de sistemas fechados e defenderei, em vez disso, o método de sistemas abertos com fechamentos parciais e temporários. Definições de sistemas fechados e abertos são examinadas. É evidente que existem muitos critérios diferentes que podem definir sistemas abertos. Os teóricos diferem em sua ênfase em um ou outro critério. Existem também diferentes dimensões de abertura: abertura a fatores não econômicos; a abertura das próprias teorias econômicas; a interação da micro e macroeconomia; e o tratamento do tempo. Estes são explorados, usando a teoria geral de Keynes como um estudo de caso de um sistema aberto.

PALAVRAS-CHAVE: Sistemas abertos; metodologia; Teoria Geral de Keynes, interpretação pós-Keynesiana.

ABSTRACT: To many, economics is seen as increasingly divorced from reality. I shall argue that one of the causes of this divorce is the attachment to closed-system theorising, and advocate instead the method of open systems with partial and temporary closures. Definitions of closed and open systems are examined. It is evident that there are many different criteria which may define open systems. Theorists differ in their emphasis on one or other criterion. There are also different dimensions of openness: openness to non-economic factors; the openness of economic theories themselves; the interplay of micro- and macro-economics; and the treatment of time. These are explored, using Keynes's General Theory as a case study of an open system.

KEYWORDS: Open systems; methodology; Keynes's General Theory; post-Keynesian interpretation.

JEL Classification: A10; B31; B40; B50; E12.

\footnotetext{
* University College London. Gower Street, London WC1E 6BT, UK. e-mail: v.chick@ucl.ac.uk. Submitted: August 2003; Accepted: September 2003.

$*$ This paper was given as the opening speech at the 8th Annual Conference of the Brazilian Society for Political Economy in Florianopolis, June 2003. I am grateful to the Board of the Society for this honour and to the participants for their comments. The paper began as a session at the ESRC Graduate Training Workshop organised by Wendy Olson in Manchester in 2002. I thank her for that opportunity and the participants for the feedback they gave me.
} 
There are many pleasures attached to being in Brazil, but one of the chief intellectual pleasures is that Brazil is still a centre of heterodox economic thought. Perhaps this is so for an unfortunate reason, namely that Brazil is beset with economic problems, and serious problems require practical solutions. Practical policy is based on knowledge of how the economy works and of its history. Already this marks a distinction with much modern neoclassical economics, which so often has little to do with the real world. The pragmatic approach also keeps one's mind open. For a pragmatist there is always the possibility that there are many ways to accomplish something - any suggestion is worth considering. This again stands apart from much modern neoclassical economics, where it is often believed that there is only one right way to proceed.

Yet we have all been taught neoclassical economics, and it "ramifies into every corner of our minds". One of the habits into which I was trained was the justdetermined system of simultaneous equations, the "model", as the main expression of theory. Through long thinking about Keynes's General Theory I have finally understood the philosophical foundations of the model approach and others like it and how far removed from that approach was Keynes's. The models are closed systems. The General Theory is an open system, in a technical sense. It is this style of theorising which I wish to talk about this evening.

I shall argue that open-system theorising has great advantages, not only for analysing economic systems but also for policy-making, though it entails some psychological disadvantages too. Open systems are only just beginning to be fairly widely discussed, however, and definitions vary. So the paper I am going to deliver explores open systems, often by contrast to closed ones, using the General Theory as an example. I hope that this will help others to construct new open-system theories to meet new challenges.

Amongst practical people with policy problems on their minds, mainstream academic economics has, or should have, a bad reputation, for its lack of realism, or worse:

The characteristics of... the classical theory happen not to be those of the economic society in which we actually live, with the result that its teaching is misleading and disastrous if we attempt to apply it to the facts of experience. (Keynes, 1936: 3.)

There is in this famous passage a direct challenge to build theory which does fit the facts of experience. In methodological terms it is a sharp rebuttal to the instrumentalist stance (the realism of the assumptions doesn't matter, only the predictive capacity of the theory; Friedman 1953). If the Colander and Klamer survey (1987) of graduate-student's perceptions have been acted upon in terms of what they learn, today's academic economists would find it difficult to rise to this challenge: they perceive "knowledge of the economy" as the skill least valued in academia and problem solving and mathematical facility as the most important (pp. 99-100). In many quarters it is the place of mathematics in this scheme of priorities 
which is believed to be the source of the divorce of economics from its subject matter, and this is certainly the case for those who follow Debreu's aim of creating an economics which is "independent of its interpretations" (1959, p. viii). But I wish to put the case that the problem arises at a stage before mathematics is brought into play: the choice of closed, rather than open, analytical systems. Mathematics encourages the closed-system approach to theory construction, but since it has been shown that mathematical methods are not incompatible with open-system theorising (Setterfield 2000, Skott 1989), and closed systems have characterised most of economics before mathematics played such a dominant role, the mathematisation of economics is neither a necessary nor a sufficient explanation.

\section{WHAT IS AN OPEN SYSTEM?}

Let us deal first with the question of system. Mearman (2002) has complained that the concept of system is underdeveloped in economics, and he is surely right. I shall deal with it very simply and also in an underdeveloped way. We speak of the economic system, the distribution system, systems of equations, a social system, a system of government, the university system, and so on. A system is a network, a structure with connections, within which agents act, mostly in ways which reproduce and reinforce the system, but sometimes in ways which lead the system to evolve. As Loasby (2002) has pointed out, in a (the?) general equilibrium system all the elements are connected with all the others, but in general the set of connections is incomplete. That is what differentiates one system from another and gives them a sense of both character and order.

Systems exist both in theory and in the real world. Theories about real-world systems are concerned to identify the agents and their actions (or, more deeply, motivations for their actions) and the channels through which those actions connect with other parts of the system. An obvious example is the capitalist system of production, in which producers, working within the structure of firms, decide how capital shall be utilised and hire labour, while people without access to capital work to earn a wage. This structure partly determines the behaviour of both sets of agents: from their position in the system it is in the interest, as perceived by an individual producer, to try to keep wages low and for workers to try to raise them. Only an understanding of the system as a whole can point out that wage income is important to the sale of the output so that low wages are not necessarily beneficial to firms.

The role of a system is often underplayed. The structural details of "the market system" of exchange are usually left vague, but it consists of a network of wholesalers and retailers and customers which has developed knowledge of the market over time. The economists' habit of specifying price as the only connecting element caused havoc when applied to the formerly planned economies as they emerged from communist rule, because the need to develop new connections, to build up a 
system, was ignored. It was simply assumed that rational agents would find their way to the best value.

Systems can be isolated or connected to other systems, usually a wider world. Isolation is part of what characterises a closed system. An open system, to remain a system, is still differentiated, but it has interactions with the outside world. In the real world, instances of perfect isolation are rare. Scientists go to considerable trouble to approximate isolation in the experimental situation; this method is not available to economists. We can model a closed economy, by which we usually mean one without international trade or payments, but real-world examples of true autarky are rare. Closure and openness in this sense are a matter of degree.

It is quite clear that not only are all parts of the economic system interconnected to a greater or lesser degree but that the economic system is embedded in and connected with politics, philosophy, history, values, all the elements of social life. Ontologically, then, the economy is unequivocally an open system. When we come to economic theory however, we have even more freedom than the experimental scientist does. Isolation is possible in thought experiments; indeed, closedsystem theorising predominates in economics. It is time to specify the criteria of closed and open systems more precisely.

\section{Criteria of closure}

Because the criteria for a closed system are quite precise, it is easier to specify these first, even though, as Mearman (2002) complains, this leaves open systems being defined negatively: an open system is one for which some or all of these criteria are not met. The Oxford English Dictionary gives the following definition:

Closed system, a complete and essentially unalterable system (of ideas, doctrines, things, etc.); a material system in which the total mass or energy remains constant; a self-contained realm, unaffected by external forces.

Dow (2002: 139-140) itemises the features of a closed system as follows: i. all relevant variables can be identified;

ii. the boundaries of the system can be specified, so that it is clear which variables are exogenous and which are endogenous; these categories are fixed; iii. only the specified exogenous variables affect the system, and they do this in

a known way (Dow says "predetermined way"); iv. relations between the variables are either knowable or random;

v. the components are separable (independent, atomistic) and their nature is

constant; vi. the structure of the relationships between the components is known (predetermined).

Dow's formulation owes much, I believe, to her work (1996) on the Cartesian mode of thought, with its categories with fixed meanings (hence the emphasis on boundaries) and on uncertainty (1995) - how can we know that we have all the relevant evidence to be certain? While in real life we cannot know, the closed system 
has within it all information needed to derive the behaviour of the system so defined, at least stochastically. The mainstream axiomatic method of theorising is the classic example of a system of this type.

Lawson (1997) approaches the definition from the standpoint of his critical realist philosophy and in the context of a critique of econometrics. Critical realism is stringently critical of the search for "event regularities" in economics. The practice of econometrics, of course, is a search for such regularities. An event regularity, or constant conjunction of events, is postulated in the form "every time event $\mathrm{x}$ occurs, event $\mathrm{y}$ follows" (shortened to "if $\mathrm{x}$ then $\mathrm{y}$ "). In the real world, event regularities are not easy to find, because of the multiplicity of forces at work; simple causal relationships are obscured. A closed system is constructed (as in an experiment) so that event regularities may be identified. He identifies extrinsic and intrinsic closure conditions. The extrinsic condition is that potential influences on y other than those explicitly taken into account (omitted variables) must be uncorrelated with the variables focused on (this is similar to but less stringent than the combination of Dow's criteria i and iii). The intrinsic closure conditions amount to Dow's criteria iv, v and vi. Agents react passively and predictably to external stimuli and are neither creative nor erratic. Note that the question of boundary where it is, how precisely it is specified - to me in many ways the most interesting matter and one on which we shall spend quite a bit of time - is not explicitly mentioned, though it is implicit in the distinction between included and omitted variables.

\section{Criteria of openness}

Open systems do not meet at least one of the above criteria, to a greater or lesser extent. But with several of the criteria, there is more than one alternative. (These asymmetries save this definition from dualism.) Dow again (p. 140):

1. It may not be possible to be sure, in a complex system, that all relevant variables have been identified;

2. the boundary of the system is semi-permeable and/or its position is not perfectly clear and/or may change; this implies that the classification into exogenous and endogenous variables may not be fixed;

3. there may be important omitted variables and/or their effects on the systemmay be uncertain;

4. there is imperfect knowledge of the relations between variables; relationshipsmay change, for example owing to human creativity;

5. there may be interrelationships between agents and/or these may change (forexample agents may learn);

6. connections between structures may be imperfectly known and/or may change; structure and agency are typically interdependent.

There is, therefore, a wide variety of types of open systems. Which criterion is emphasised is of great importance. Critical realists, because of their scepticism about event regularities, tend to concentrate on criterion 4: the possibility that the 
internal relations between variables may not be constant, so that open systems are perceived as not presenting constant conjunctions of events. If this means that events in open systems present a chaotic appearance, this is not a happy state of affairs, either to those who wish to infer underlying mechanisms from perceived event regularities or for those who perceive causal relations at the level of events themselves. On this criterion it could be thought that open systems are inimical to and incompatible with theory. (Mearman (2002) points out that it is rather odd, given critical realists' concern with underlying mechanisms that their characterisation of open systems stays at the level of events.)

There must be sufficient regularity to allow analysis, but this is not to rule out all change. Change can come about because agents learn or because structures or their connections alter in some way. An open system can evolve. While mutability is an implicit feature of most of the criteria above $(2,4,5$ and 6$)$, it is made explicit in the OED definition of an open system, as immutability was, above, for closed systems:

open system, a material system in which the total mass or energy fluctuates; an incomplete or alterable system (of ideas, doctrines, things, etc.).

Setterfield (2000) stresses path-dependence, in which agents make crucial decisions that change the future. Caserta and Chick (1997), Chick (1983 Ch 2), Chick and Dow (2001), Dow (2002) and Kregel (1976) emphasise boundaries and the suitability of shifting them, especially the necessity of partial and provisional closures to suit the theorist's needs.

At this point, however, we have probably been speaking in the abstract for a bit too long. Let us give some examples of open systems and their application.

\section{DIMENSIONS OF OPENNESS}

\section{Subject matter}

How does one know that one is doing economics rather than something else? In other words, what are the borders of economics as a subject? Clearly, in the world, economics is embedded in society and its thought-systems, but the subject, as a body of analysis or field of enquiry, can be defined - has been defined - in very narrow and closed ways. There is Robbins's famous definition that economics is the study of the allocation of scarce resources (1932). The early Joan Robinson (whom the later Joan repudiated) considered economics to be coterminous with its technique (1932). Today there is a view that anything which falls outside the mainstream formalist method is somehow "not economics". This view seeks to insulate economics not only from other disciplines but even from other methods - an echo perhaps of Robinson 1932. Other theorists respected few borders between economics and other disciplines, but the extent of permeation is variable and it is never 
complete. Much work was done in the 1980s and 1990s on the relationship between Keynes's epistemological, political and ethical philosophies and his economics (Bateman 1987, Carabelli 1988, Davis 1994, Fitzgibbons 1988, Helburn 1991, O'Donnell 1989 and many more). The political philosophy behind the work of Friedman or Lucas is also transparent. One can think of many examples.

\section{Object of study}

Mainstream economics proceeds by developing models, usually of the closedsystem type, especially in the form of a system of simultaneous equations. These are so familiar as hardly to need rehearsing. It is sufficient to note the fulfilment of the criteria for closed systems. The theorist decides his/her quaesitum, which variables are relevant to its explanation and what are the exogenous variables. These categories and the postulated relationships between the variables are fixed. The closure conditions are satisfied. The system is processed to yield its solution, which is called equilibrium. If the rules of mathematics have been obeyed, the model exhibits internal consistency, which is the criterion of acceptance of such models.

There is an argument, which I have heard put forward by Frank Hahn (EAEPE speech, Valencia; not published) that because the experimental method is not available to economists, internal consistency is the only test of rigour and criterion of theory acceptance. Let us be clear that the corollary of this proposition is that only closed-system theorising is acceptable. Cartwright (1999) has put the claim for external instead of internal validity. External validity is what is often called realism or "realisticness" or applicability to the real world. As a counterweight to Hahn's argument this term has rhetorical power. We return to this matter later.

An obvious example, well-known to us all, is of course ISLM. In the simple reduced-form system, $M^{*}=k Y+1(r), s(Y)=I(r), M$ is the exogenous variable; the other variables jointly determine $\mathrm{Y}$ and $\mathrm{r}$ for the given level of $\mathrm{M}$, and that solution holds unless and until $\mathrm{M}$ changes.

Contrast that with the elaborate framework of the General Theory. I once compared the structure of the General Theory to a complex play (1983, Table 2.1, pp. 29-32). I had forgotten Shackle's characterisation until reminded by Hawkins and Torr (2002: 182):

At each curtain rise the General Theory shows us, not the dramatic moment of inevitable action but a tableau of posed figures. It is only after the curtain has descended again that we hear the clatter of violent sceneshifting. (Shackle 1967: 182.)

It is a play no dramatist could get away with: there are too many acts and scenes. Perhaps that is why most people focus on only part of it and become "Chapter 12 Keynesians" and the like. In terms of open systems, however, it is a perfect example of how to handle a complex subject without resorting to reductionism, through the device of taking first one element of the overall system, then another, 
as the object of analysis, using the method of ceteris paribus to provide a closure for each partial system and later removing it. The first chapter setting out the new theory, Chapter 3, explains the relation between demand and income in terms of the marginal propensity to consume but makes no attempt to explain investment when aggregating to output as a whole: it is taken as given. We are in the short period: investment is part of aggregate demand but does not affect supply conditions; from the point of view of production the capital stock is given. Both longperiod and short-period expectations are taken as given, and since the latter are also are assumed to be met, the point of effective demand, where aggregate supply meets aggregate demand, is a position from which there will be no change as long as the system is not disturbed. This is a model closed by the assumptions just noted. It determines the (equilibrium) level of employment; the point, of course, is that in this level it isn't necessary full employment. Kregel (1976) calls it the static model. (Curiously, Keynes remarked after he had finished the book that if he had it to do over again he would start with the situation in which expectations were met - but he had done just that!)

In Chapter 5 the same model's disequilibrium properties are explored. It is still true that output and employment are determined by producers' short-period expectations, but now there is no assumption that these are correct. The determination of output and employment by producers' expectations is emphasised: actually realised results will only affect employment in future if they alter producers' expectations. The level of aggregate demand is taken as given, so that short-period expectations can "catch up" with actual demand. Kregel calls this the stationary model.

In Chs 8-10 the borders of the model change again; having raised the question of actual, as opposed to effective, aggregate demand, actual demand now needs to be explained, starting with the consumption function. The spotlight shifts away from producers to households, where consumption decisions are made. The multiplier provides a mechanism of adjustment for the model of Chs 3 and 5 when the level of demand changes. The most likely cause of change is a shift in long-term expectations; because the basis of these in anything objective or known is so fragile, they are always likely to be volatile. Animal spirits are perhaps even more volatile. The system of changing levels of investment is Kregel's "shifting equilibrium" model. But the explanation of the volatility of investment and its reinforcement by liquidity preference has to wait for Chs 11-13 and 15-16, which deal with the determination of investment and the rate of interest.

In $\mathrm{Ch} 17$ the assumption that investment will not affect supply is relaxed and a question pertaining to the long period is asked: will the incentive to invest dry up before or after the incentive to save? If the former, which Keynes argued was more likely because of the floor to the rate of interest given by money's liquidity premium, income would have to fall to bring saving in line with investment. Thus full employment would be unlikely to characterise the long period, in sharp contrast to the classical assumption.

Then the theory is summarised (Ch 18) and implications drawn: the consequences of changes in money wages are analysed (Ch 19), the determination of the level of 
employment is elaborated (Ch 20), and a theory of prices developed (Ch 21) before going outside the confines of the theory itself to indicate further consequences.

The central point of this little sketch is to show that the General Theory provides a single theory within which are several subsystems, each defined by a change in the ceteris paribus assumptions that define its borders. In this sense it is an open system comprising several closed models with different quaesita or dependent variables and exploring a different aspect, but they fit together. The General Theory fits perfectly the template proposed by Caserta and Chick (1997) and Chick and Dow (2001) for dealing with systems too complex to analyse in one go: results are obtained by making closures which are partial and provisional. Some examples of partial closure are the following: in Ch 19 most of the analysis concerns a closed economy, but international trade makes a brief appearance; the government sector does not feature prominently in the book but the importance of the method of financing public works comes up on p. 200. The closures are all provisional, changing rather like the partitions in a Japanese house to suit the varying needs of the day. They are not meant to stay in place for long but to be swept away in order to look at another aspect. Categories are not fixed. The border between consumption and investment, for example, is open to several interpretations (see Chick 1983, Table 3.3: 42-3), and it is not absolutely clear that one interpretation is held by Keynes throughout the book. A slippery definition of the money supply is defended (p. 167, $\mathrm{n}^{\circ} 1$ ) and, I would argue, is evident in liquidity preference (Chick 1981, 1991). The provisional character of the closure makes any equilibrium obtained under its assumptions also provisional. (Setterfield, who has developed very similar ideas independently, uses the word conditional.)

\section{Time}

Economics has a terrific problem with time. Whole books are written on the subject (Currie and Steedman 1990, Vickers 1994). Hicks let a very important cat out of the bag when he wrote:

[The ISLM diagram] is now much less popular with me than I think it still is with many other people. It reduces the General Theory to equilibrium economics; it is not really in time. That, of course, is why it has done so well. (Hicks, 1976: 289-90.)

Time plays havoc with closure, for time begins with the Big Bang and its end is, we hope, similarly remote, at least for the world in general if not for ourselves in particular. No theory, closed or open, is going to deal with the whole of history. In economics there are time-honoured ways of abolishing time: static analysis, which is truly timeless; analysis in terms of rates of change, as in much of growth or inflation theory, and convergence to an asymptote, which is the end-point of the analysis, often equated with a long-run result. In conventional dynamics, too, time is abolished, for despite having dated variables, everything necessary to define the 
whole trajectory of the variable in question is known at the beginning. The trick in general equilibrium analysis of defining state-contingent choices is also a device for bringing the future back to the present. As is necessary in closed systems, all future states are assumed to have been identified; this is a world without surprises, which exists independently of its agents.

How do open-system theories cope with time? There are different time-scales in this question. Let us take first the sweep of history. No one is going to theorise about the economic system of single-celled organisms in the primoeval ooze - no data, for a start. So we know that only part of history can be taken into account. The question is which part. History manifests itself in economic systems as changing networks and institutions, conventions, social systems and behaviour. Open systems can allow for the influence of history by means of the same device that was explored above: the partial and provisional closure. A theory relevant to the industrial revolution is not going to be very helpful to explain these days of advanced and global finance capitalism. A theory of money and prices based on full-bodied coin (the quantity theory) is not much helpful when the bulk of the money supply is generated through bank lending. A measure of the labour force common in the 1960s, able-bodied males between the ages of 16 and 65, has a very dated air. A prime example of new circumstances requiring new theory is found in Keynes's theory of liquidity preference: with the growth of active trading in the stock of existing financial assets, loanable funds theory, based as it is on new lending and borrowing, was hopelessly misleading. Similarly, the evolution of the banks into a system which could lend without any corresponding prior saving was responsible for reversing the causality between saving and investment of the classical economists (Chick 1986). History can make a theory which was right for its time become wrong as the economy evolves and the theory ceases to capture the salient relationships. It is for the theorist to judge whether a period of time has sufficient uniformity or coherence to make it a suitable subject for theory. The General Theory pertains to an advanced capitalist system. Its relevance to developing countries is open to debate: one obvious difference concerns the stage of development of the financial system which is assumed (Studart 1995).

History also plays a narrower role in the General Theory, well explained by Joan Robinson (1978, p. ix): the theory starts as the economy starts every new day, with a stock of capital inherited from the past. This capital defines possibilities, in particular for production. Even when planning an expansion of capacity, one has to produce with the capital one has already. Thus the use of the Marshallian short period when output and employment are the dependent variables makes sense. It is realistic. And in the context of the 1930s, when the rate of investment was very low, this short period went on for quite a long time! (Chick 1983b).

There is a tension in the General Theory between timefulness and timelessness which once again illustrates the technique of partial and provisional closure. There is the prospect of path dependency in the General Theory: when short-period expectations are not fulfilled, producers may change those expectations. (I say "may" because one observation of falsified expectations is never enough, in a system which 
is subject to uncertainty and unexpected variation, to justify a change. This is a problem of signal extraction: distinguishing signal from noise requires several observations.) One observation cannot identify whether the expectation is correct, either - it could be a fluke. But suppose producers do change their expectation of demand. Since both price and output change at every point on both the aggregate supply curve and the expected demand curve, when one curve changes the other will also; it is only money wages which are constant along these curves, and profitability depends also on sales - output and prices. It is difficult to say where the system will end up.

Another example is the multiplier. If you read the chapter on the multiplier carefully, Keynes explored two sets of possible price configurations following what these days would be called a demand shock, depending on the degree of foresight in the wage-goods industries. No textbook has ever, to my knowledge, recognised this, nor has it been commented on in research articles. The further problem that the interest rate is bound to change as the multiplier progresses, with repercussions for investment, was not even touched upon in the General Theory.

So the system is path-dependent, but since there are many possibilities a precise path is (wisely) not chosen and modelled, so nothing definite can be said. This is not very satisfactory: people want results. In the absence of the technique of simulation, not available to Keynes, he cut through the limitless possibilities by the use of shortperiod equilibrium. This is possible, even in a system which is inherently path-dependent, and it extracts from limitless possibility one configuration about which a good deal can be said, without foreclosing the path-dependency. This is made possible by the partial closure of the short period, which creates a subsystem in which time is suspended. The same is true of the long period, though the criterion of correct expectations does not apply; rather the criterion is accumulation up to the point where the marginal efficiency of last unit of the stock of capital equals the rate of interest.

\section{The relation between micro and macro}

The charge that Keynesian macroeconomics has no microfoundations is wearily familiar, and unresolved. There is a sense in which this charge is absurd, but there is some truth in it, too. It is absurd in the sense that the General Theory discusses motivation and decisions - to consume, to produce, how liquid to be, how much labour to hire, what wage to offer and to accept — which can only be taken by individuals acting on their own account or as representatives of organizations. On these points both those sympathetic to Keynes and the sceptics - if they could bring themselves to read the book at first hand - could easily agree. But there is truth in the allegation that the link between these micro elements and the macro theory is incomplete and imperfect. There are good reasons for this. The economy, and this theory of it, is a complex system, where the interaction of plans produces surprising results, unintended consequences of individual actions. The paradox of thrift; the possibly adverse effect on employment of a fall in money wages; the 
dual role of money, "lulling our disquietude" while causing a signalling problem for producers; the ability of securities markets to provide liquidity to the individual while not being able to do so for system as a whole - these are all examples of the impossibility of generalising from micro decisions to macro outcomes: the fallacy of composition.

From the fallacy of composition it follows that, short of specifying every transaction and the precise time that it takes place, the link between micro and macro not only is not tight but cannot be tight. It is bound to be ambiguous. Neoclassical economics has its own ways of dealing with this problem. One way or another they rely on the representative agent. Either the macroeconomic relations are worked out and then each individual is assumed to replicate $1 / \mathrm{nth}$ of the aggregate, as it were, or individual behaviour is postulated and aggregated, on the assumption of atomism, to form the macro. The fit is perfect and the system as a whole is closed. Rational expectations allow individuals to be ignorant of "the correct model" for a time but gradually to correct their understanding of the system so that they replicate it.

Keynes's system, however, is open, potentially in both directions. Micro agents act, but their interaction (the "system") may confound their intentions. They may learn from this, creating conventions to improve stability, for example, and by so doing change the macro-system. The latter possibility was one of the things kept at bay by ceteris paribus in the General Theory but perfectly possible within the theory outlined there. The ambiguity is inescapable. Sometimes the macro proposition is derived by a method more familiar in econometrics: by assuming that variations in behaviour are randomly distributed. Though the General Theory is not explicit, this is how I think one can interpret the consumption function. Or a choice may be made to construct a compromise in which certain micro aspects are sacrificed to preserve important aspects of the macro system. This is my interpretation of Keynes's treatment of investment (Chick 2002). I used the phrase "necessary compromise" to call attention to the fact that if nothing short of full knowledge of every event can solve the micro-macro problem in a way which would satisfy the neoclassicals, we had better accept that compromises are inescapable. Simply to reverse the question and call for macrofoundations of microeconomics is to stay within the confines of closedsystem thinking that is at the root of the problem in the first place. And the representative-agent model — which is itself a compromise — does that already.

\section{CONCLUSIONS AND IMPLICATIONS FOR POLICY}

In Macroeconomics after Keynes (Chick 1983a) I portrayed the General Theory as an open theoretical system without using the phrase. I was quite vague about the concept. Now that open systems are beginning to be discussed and developed we can see more clearly the radical nature of the book and be in a better position to take lessons from it. A theory is broader than a model and can contain many 
models, depending on how the models (sub-systems) are created by assumptions and ceteris paribus conditions. Many more could be created within Keynes's theory: technological change could be introduced, the generation of money by bank credit could be incorporated, there could be theories of the evolution of conventions or the formation of expectations or of wage bargaining; the list is almost endless. People are, of course, working on these things, but at the moment not integrating the pieces into a larger scheme.

The strength of the General Theory was in choosing the right abstraction for the time, to see the important connections between the structures (economic institutions) and identify key elements of economic behaviour, and then to find partial and temporary closures which allowed the theory to be developed and explained without these closures distorting the theory. Just to clarify the question of distortion, consider another macro-system, that of Walras (1954 [1926]). Walras quite explicitly used the model of exchange first and then extended it to production. In exchange all (or most) things are substitutes, so in Walras the trade-off (price) between labour and output is given by the real wage. But the crucial fact of production is that labour and output are complements; the real wage then is both a cost to the firm and the main source of its sales. The reason Keynes could see that point is that his system concerned production, containing exchange as a sub-system. Walras's theory of exchange was a closed system, not really extendable to production as he thought.

Open systems are psychologically hazardous. They offer few certainties. Classical logic is only usable in closed systems and therefore an open system cannot produce demonstrable conclusions. The internal consistency criterion of theory appraisal is not available, because compromises will have to be made. The question as to whether they are good compromises is a matter of judgement. One cannot prove that one's judgement is good; one can only try to persuade. And it is difficult to say that any theory is wrong: to paraphrase Keynes, "I cannot convict my opponent of error; I can only convince him of it". The theorist must constantly exercise judgement - in identifying the important structures, connections and behaviours, in choosing the appropriate partial and temporary closures, in choosing which chains of reasoning to follow, and in appraising theories.

Where policy is concerned there is a list of costs and benefits too. Policymakers are as attracted by the promise of certainty as anybody else, but economists have a duty not to give them certainty when it doesn't really exist. It has been suggested to me that academic members of the Monetary Policy Committee of the Bank of England were much more ready to favour larger changes in the rate of interest than were the banker members. This difference was attributed (rightly or wrongly, but interestingly) to the academics' higher degree of belief in the models the Bank uses to inform the Committee. (The more careful examination by Cobham, 2003, does not draw this conclusion.) A more extreme example of the mis-use of certainty is Milton Friedman's instant prescription of monetary stringency, hot off the aeroplane wherever he has landed. Thinking in terms of open systems entails a recognition of complexity and its unintended consequences, uncertainty, and incompleteness - in other words of one's own fallibility. This leads to caution and 
gradualism. It encourages recognition that the economic system is not objective but created, partly by policy, and that agents will learn to adapt their behaviour to circumvent inconvenient policies. This only renders policy-makers obsolete if they are stupid, as in the Lucas critique, or (equivalently?) if they believe in closed systems, so that adaptive behaviour comes constantly as a surprise. A policy-maker guided by open-system thinking is cautious, is conscious of potential surprise, and keeps alert, trying to anticipate the next move. This strikes me as a sensible and desirable policy attitude.

\section{REFERENCES}

BATEMAN, B. (1987) “Keynes's changing conception of probability”. Economics and Philosophy 3 : 97-119.

CARABELLI, A. (1988) On Keynes's Method, Macmillan.

CARTWRIGHT, N. (1999) “The vanity of rigour in economics”, LSE Centre for philosophy of Natural and Social Science Discussion Paper 43/99.

CASERTA, M. and V. CHICK (1997) "Provisional equilibrium and macroeconomic theory", in P. Arestis, G. Palma and M. C. Sawyer, (eds.), Markets, Employment and Economic Policy: Essays in Honour of G. C. Harcourt, vol. 2, Routledge: 223-237.

CHICK, V. (1981) "On the structure of the theory of monetary policy", in D. Currie, R. Nobay and D. Peel (eds.), Macroeconomic Analysis: Essays in Macroeconomics and Econometrics, Croom Helm, London: 178-208.

CHICK, V. (1983a) Macroeconomics After Keynes: A Reconsideration of the General Theory, Philip Allan, Dedington, Oxford and MIT Press. In Portuguese: A Macroeconomia após Keynes: Um Reexame da "Teoria Geral", Editora Forense Universitária, 1993.

CHICK, V. (1983b) “A question of relevance: The General Theory in Keynes's time and ours”, South African Journal of Economics, 5, September: 388-406.

CHICK, V. (1986) "The evolution of the banking system and the theory of saving, investment and interest", Economies et Societes, Cahiers de l'ISMEA, Serie “Monnaie et Production", n 3, 1986: 111-26. Published in Portuguese as "A evolução do sistema bancário e a teoria da poupança, do investimento e dos juros”, Ensaios FEE (Fundação de Economia e Estatística, Porto Alegre), vol. 15, no 1, 1994: 9-23.

CHICK, V. (1991) "Hicks and Keynes on liquidity preference: a methodological approach", Review of Political Economy 3, $\mathrm{n}^{\circ}$ 3: 309-319.

CHICK, V. (1998) “A struggle to escape: equilibrium in The General Theory”, in S. Sharma (ed.), John Maynard Keynes: Keynesianism into the Twenty-First Century, Edward Elgar: 40-50.

CHICK, V. (2002) "Keynes's theory of investment and necessary compromise", in S. C. Dow and J. Hillard (eds.), Beyond Keynes, vol. 2: Keynes, Uncertainty and the Global Economy: 55-67.

CHICK, V. and DOW, S. C. (2001) "Formalism, logic and reality: a Keynesian analysis", Cambridge Journal of Economics 25 (6), November: 705-22.

COBHAM, D. (2003) "Why does the Monetary Policy Committee smooth interest rates?", Oxford Economic Papers 55: 467-93.

COLANDER, D. and KLAMER, A. (1987) "The making of an economist", Journal of Economic Perspectives 1 (2): 95-111.

CURRIE, M. and STEEDMAN, I. (1990), Wrestling with Time, Manchester University Press.

DAVIS, J. B. (1994) Keynes's Philosophical Development, Cambridge University Press.

DOW, S. C. (1995) "Uncertainty about uncertainty", in S. C. Dow and J Hillard (eds.), Keynes, Knowledge and Uncertainty, Aldershot, Edward Elgar.

DOW, S. C. (1996) The Methodology of Macroeconomic Thought, Cheltenham, Edward Elgar. 
DOW, S. C. (2002) Economic Methodology: An Inquiry, Oxford University Press.

FITZGIBBONS, A. (1988) Keynes's Vision, Clarendon Press, Oxford.

FRIEDMAN, M. (1953) “The methodology of positive economics”, Essays in Positive Economics, University of Chicago Press.

HAWKINS, P. A. and TORR, C. W. S. (2002) "Unemployment in a small open economy", in P. Arestis, M. Desai, and S. C. Dow, eds, Money, Macroeconomics and Keynes, Routledge.

HELBURN, S. (1991) "Burke and Keynes" in B. Bateman and J. B. Davis (eds.), Keynes and Philosophy, Aldershot, Edward Elgar.

HICKS, J. R. (1976) "Some questions of time in economics", in A. M. Tang, F. M. Westfield and J. S.

Worley (eds.), Evolution, Welfare and Time in Economics, Lexington MA, Lexington Books.

KEYNES, J. M. (1936) The General Theory of Employment, Interest and Money, Macmillan.

KREGEL, J. A. (1976) "Economic methodology in the face of uncertainty: the modelling methods of Keynes and the Post-Keynesians", Economic Journal 86 (June): 209-25.

LAWSON, T. (1997) Economics and Reality, Routledge.

LOASBY, B. J. (2003) “Closed models and open systems", Journal of Economic Methodology, forthcoming.

MEARMAN, A. (2002) "A Contribution to the Methodology of Post Keynesian Economics", PhD thesis, University of Leeds.

O’DONNELL, R. (1989) Keynes: Philosophy, Economics and Politics, Macmillan.

ROBBINS, L. C. (1932) An Essay on the Nature and Significance of Economic Science, Macmillan.

ROBINSON, J. (1932) Economics is a Serious Subject, Cambridge, Heffer and Son.

ROBINSON, J. (1978) "Introduction - 1978", in J. Robinson, The Generalisation of the General Theory and Other Essays, Macmilan, 1979.

SETTERFIELD, M. (forthcoming, 2003) "Critical realism and formal modelling: incompatible bedfellows?", Applied Economics and the Critical Realist Critique, London: Routledge.

SHACKLE, G.L.S. (1967) The Years of High Theory, Cambridge University Press.

SKOTT, P. (1989) Conflict and Effective Demand in Economic Growth, Cambridge University Press.

STUDART, R. (1995) Investment Finance in Economic Development, Routledge.

VICKERS, D. (1994) Economics and the Antagonism of Time, Ann Arbor, University of Michigan Press.

WALRAS, L. (1954 [1926]) Elements of Pure Economics, trans. of 1926 edition by W. Jaffe, George Allen and Unwin. 